\title{
Foreign Direct Investment And Macro Variables: 2010- 2019 An Implementation For Turkey
}

(Research Article)

Doğrudan Yabancı Yatırım ve Makro Değişkenler: 2010-2019 Türkiye Iç̧in

Bir Uygulama

Doi: 10.29023/alanyaakademik.676878

Cumhur ŞAHIN

Dr. Öğr. Üyesi, Bilecik Şeyh Edebali Üniversitesi, Bozüyük MYO

cumhur.sahin@bilecik.edu.tr

Orcid No:0000-0002-8790-5851

How to cite this article: Sahin C. (2020). "Foreign Direct Investment And Macro Variables: 2010-2019 An Implementation For Turkey”, Alanya Akademik Bakış, 4(3), 755-769.

Keywords:

Foreign Direct

Investment,

Macro variables, Time

Series Analysis

Received: 19.01.2020

Accepted: 02.09.2020

\begin{abstract}
Among the factors of production, the most needed factor in developing countries is capital. Capital transfer between countries has become very important with the acceleration of globalization. In this context, it is seen that developing countries focus more on foreign direct investment in terms of their economic development. In this study, the relationship between foreign direct investment and consumer price index, indicator interest rate, GDP and trade openness ratio which are thought to affect these investments are analyzed for Turkey's case, as of the last decade between the first quarter of 2010 and the fourth quarter of 2019. According to the empirical findings, it was found that the variables were cointegrated in the long term, in other words, the variables were related to each other in the long term and moved in the same direction.
\end{abstract}

\section{INTRODUCTION}

Foreign direct investment is an international investment made by an enterprise established in an economy (individual enterprise, anonymous or ordinary public or private enterprise) to establish a long-term relationship in another country. The long-term relationship refers to the existence of a long-term relationship between the foreign direct investor and the foreign direct investment entity and the sufficient influence of the direct investor in the management of the entity. Foreign direct investment has striking effects on economic growth, capital accumulation, balance of payments, employment, technological development and technology transfer, especially in terms of the host country receiving the investment. When the situation is analyzed in terms of foreign direct investment coming to Turkey, it is seen that foreign direct investment to Turkey has increased significantly after 1980 compared to the previous periods. This increase has been particularly influenced by the abandonment of the stabilization program and the import substitution system of January 24, 1980, and the implementation of an open, liberal and export-oriented approach instead. However, the 
crucial period in terms of foreign direct investment coming to Turkey is after 2000. Turkey's economy has become more outward together with the new dynamics affected and structured by the crisis in 2001. Through the privatizations, an understanding that limited the role of the state in the economy was adopted.

\section{LITERATURE REVIEW}

There are many studies in the literature regarding macroeconomic variables that affect foreign direct investment. It is possible to summarize the major ones, especially the ones published during the last twenty years, as follows.

In the study of Reicher and Weinhold (2001:153), direct foreign investment and economic size data of 24 countries between 1971 and 1995 were used. Contrary to previous findings, this study suggests that other domestic investment, net foreign direct investment, positively affect the economy of the country. In addition, it is stated that foreign direct investment will have a positive effect on some countries but this is not a homogeneous result. Alguacil et al. (2002:371) investigated the relationship between foreign direct investment and GDP for Mexico between the first quarter of 1980 and the fourth quarter of 1996. Data were analyzed by the Toda-Yamamato and Dolado-Lutkepohl methods. One-way causality relationship from foreign direct investment to GDP was determined as a result of the data analysis. As a result of Aseidu's study (2002:107) which investigates the economic factors that are assumed to have an impact on foreign direct investment in selected African countries (2002:107), it has been found that per capita income has a significant and positive effect on foreign direct investment. Hansen et al. (2003), studied data of China, Malaysia, Vietnam, Indonesia, and Thailand between 1988 and 2000. In this study, they observed that there is a causality relationship from economic growth to direct foreign investment and that there is no causality relationship from direct foreign investment to economic growth. In their study of panel data regression analysis (2003) for the 1990-1998 period for the 25 transition economies, Campos and Kinoshita concluded that market volume had a significant effect on foreign direct investment. Alic1 and Ucal (2003) tested the causality relationship between export, direct capital flows and industrial production index series with the Toda-Yamamoto approach in their study in the period between the first quarter of 1987 and the fourth quarter of 2002 for Turkey. According to the causality results, one-way causality from export to economic growth was found. However, no causal relationship was found between direct capital investment and exports. It was found that there was no causal relationship between direct capital investment and economic growth. Dumludag and Sukruoglu (2007:161) investigated the role of institutional variables as well as the role of macroeconomic inflows in foreign direct investment inflows to developing countries. In this study, it was found that macroeconomic variables such as market size and growth rate have a positive effect on foreign direct investment inflows. However, as a result of the study; it is seen that the functioning of the judicial system, stable government, investment environment, internal and external conflicts, and socioeconomic conditions also have a significant effect on the inflow of foreign direct investment in developing countries.

Michailova and Ang (2008:551) investigated factors that were supposed to have an impact on foreign direct investment in Malaysia and revealed a significant and positive effect of GDP size and GDP growth on foreign direct investment. In his study on the determinants of foreign direct investment in Latin American countries, Montero (2008:55) utilized the timeseries cross-sectional data of 15 countries between 1985 and 2003. It was concluded that good 756 
governance and reform variables have an inconsistent effect on foreign direct investment. Pradhan (2009:153) investigated the 1970-2007 period of ASEAN countries using the panel causality method. As a result of the study, it was stated that there was a two-way causality between direct capital investment and economic growth for Indonesia, Philippines, Singapore, Thailand, while there was no causal relationship between direct investment and economic growth in Malaysia. In the study of Koyuncu (2010:61), the effects of macroeconomic variables such as trade openness rate, interest rate, real exchange rate, net international reserves, inflation rate (WPI) and GDP on foreign direct investment were analyzed by using the data of 1990-2009 period. As a result of the VAR analysis, it was found that foreign direct investment inflows were significantly affected by the amount of previous period foreign direct investment, gross domestic product, trade openness and changes in net international reserves.

In the study of Gürsoy and Kalyoncu (2012:270), the relationship between Georgia's direct foreign investment and economic growth was investigated using the data between 1997 and 2010. It was found that there was causality relationship from the foreign direct investment to the economic growth variable and the variables tended to move together in the long term. In the study of Villaverde and Maza (2012:722) on macroeconomic variables that are thought to affect foreign direct investment in Spain, it was determined that economic potential, labor conditions, competitiveness, GDP have a significant and positive effect on foreign direct investment. Marjanovic and Marjanovic (2014:1443), in their study on the variables that affect the foreign direct investment in Serbia, have determined that the employment rate and the share of industry in total production, as well as the size of GDP, affect foreign direct investment.

The economic relationship between foreign direct investment and economic size for 28 countries, including Turkey, was investigated in Shahbaz's study (2014:9). While no relationship was found for a short term, the causality relationship was determined from foreign direct investment to economic size in the long term. Portilla et al. (2016:80) investigated foreign direct investment in Spain for the period 1997-2013. In this study, it was found that the factors affecting foreign direct investment flows were market volume, GDP, level of human capital due to interaction with wages and Madrid's own characteristics. In the work of Topallı (2016:93), the relationship between direct capital investment, trade openness and economic growth in Turkey and in BRICS countries in the 1982-2013 period, were examined. CADF unit root test and Emirmahmutoğlu and Köse (2011) causality tests were used to investigate the relationship. The results showed that there was a one-way causality from economic growth to foreign direct investment. In Sunde's study (2017: 434), the relationship between GDP and FDI between 1990 and 2014 for South Africa was investigated and as a result, the causality relationship was determined from FDI to GDP in the short and long term. In the study conducted by Randelovic et al. (2017:102), they investigated the effects of market volume and market growth rate on foreign direct investment in Western Balkan countries. It was seen that these variables had a significant and positive effect on foreign direct investment.

In the study of Yorulmaz et al. (2018:168), the variables that are emphasized to have an impact on foreign direct investment in the literature were evaluated with multivariate statistical methods instead of evaluating from an econometric point of view. Based on the World Bank 2014 data, OECD, Middle East, Latin American countries were analyzed. In the 
first stage of the study, the units were taken as variables. Taking into account the relationship between various macroeconomic, social and institutional dynamics that affect foreign direct investment, these three different groups of countries from the Middle East, OECD, Latin America were compared with multidimensional scaling, a dimensional reduction technique based on the matrix of distances. In the second stage, homogeneous country groups within the country groups of interest were determined by cluster analysis and the findings were evaluated. It was seen that variables affecting foreign direct investment in the Middle East and Latin American countries were not macroeconomic variables, but rather political stability, level of corruption and democracy. It was determined that Turkey had a similar structure with Jordan, Lebanon, Israel and Tunisia from Middle Eastern countries and with Korea from OECD countries in terms of foreign direct investment and related factors.

\section{METHOD, MODEL and DATA SET}

In the study, quarterly data between 2010-2019 were compiled from Turkey's Statistical Agency, OECD, The Central Bank of the Republic of Turkey and the World Bank data distribution system. Using this data, the relationship and connection between foreign direct investment, consumer price index, benchmark interest rate, gross domestic product, trade openness ratio were investigated. Foreign direct investment was used as a dependent variable and consumer price index, benchmark interest rate, gross domestic product and trade openness ratio were used as independent variables. The effect of consumer price index, benchmark interest rate, gross domestic product, trade openness ratio on foreign direct investment was analyzed within the framework of the following model.

$\mathrm{FDII}=\beta 0+\beta 1 \mathrm{CPI} \dot{\mathrm{I}}+\beta 2 \mathrm{BIRI}+\beta 3 \mathrm{GDP} \dot{\mathrm{I}}+\beta 4 \mathrm{OR} \dot{\mathrm{I}}$

FDI $=$ Foreign Direct Investment dependent variable,

$\mathrm{CPI}=$ Consumer Price Index, that is, the inflation rate,

$\mathrm{BIR}=$ Benchmark Interest Rate,

GDP $=$ Gross Domestic Product

OR $=$ Trade Openness Ratio

Time series were used and analysis was performed in Eviews 9 package program in this research. It is very important that the series in this model be in a static structure for the econometric model to move forward in a meaningful way. Time series in the variables were investigated in order to achieve this. If they were not investigated, unreal relationship structures would emerge and the problem of false regression would be encountered (Granger and Newbold, 1974). The relationship between direct foreign investment, consumer price index, benchmark interest rate, gross domestic product, trade openness ratio was investigated while the stability of the variables was tested with ADF and PP unit root tests. After these series were stabilized, the relationships in the econometric model were considered separately for the long and short term. Engle-Granger and Johansen Cointegration tests were used to demonstrate the long-term relationship. However, first of all, VAR estimation should be made for this and the appropriate number of lags should be determined based on VAR. A cointegration relationship was determined in the long term by looking at the appropriate lag numbers in the analysis. It was determined that the VECM model would be more appropriate than the VAR model according to this result. Therefore, the relationship between the 
variables in the analysis was determined by using the VECM model. The causality and direction of the relationship were examined together for the variables included in this model. The Granger Causality test was applied and the test results were recorded to achieve this.

\section{FINDINGS}

Table 1 shows the descriptive statistics of the data used in the study.

Table 1. Descriptive Statistics

\begin{tabular}{|l|c|c|c|c|c|}
\hline & BIR & CPI & FDI & GDP & OR_ \\
\hline Mean & 10686.88 & 9.856250 & 2273.250 & 4.337500 & 15.75900 \\
\hline Median & 9390.000 & 8.835000 & 2098.000 & 4.350000 & 16.10000 \\
\hline Maximum & 23610.00 & 24.52000 & 5640.000 & 12.20000 & 19.27000 \\
\hline Minimum & 5140.000 & 3.990000 & 240.0000 & -3.000000 & 9.260000 \\
\hline Std. Dev. & 4047.516 & 4.103879 & 1172.008 & 3.645910 & 2.361800 \\
\hline
\end{tabular}

\section{Unit Root Tests}

PP and ADF unit root tests were used to investigate the stability of the series. The PP test can be used to prevent autocorrelation and in case the error terms have a changing variance due to using a non-parametric method. ADF test, on the other hand, completely eliminates the problem of autocorrelation. A lag length where the error term will generate white noise is determined for the whole series in these two root terms. Multiple information criteria are used to determine the lag length in these tests. The most commonly used criteria are Akaike (ACI), Schwarts (SIC), Final Prediction Error (FPE), Hannan-Quinn (HQ) and (LR) (Johansen, 1995; Enders, 1995).

\section{ADF Unit Root Test}

The hypotheses in the ADF test show different results. The null hypothesis states that the series is not stationary, whereas the opposite hypothesis states that the series is stationary. It is possible to show the constant only ADF test by equation (1) (Asteriou \& Hall, 2007);

$\Delta y_{t}=\beta+\delta y_{t-1}+\sum_{i=1} \emptyset_{i} \Delta y_{t-1}+\varepsilon t$

In order to reject the null hypothesis in the ADF test, the variable Y should be assumed to be stable at its original level. Otherwise, it turns out that it is not already stationary. As can be seen from the equation, differencing must be performed to the series in order to make a nonstationary series stationary. If the series becomes stationary when the differencing is performed for the first time, these series are called as integrated of order 1. Differencing process repeats until getting a stationary series. The t-statistic computed in equation 1 is compared with the MacKinnon critical values to determine whether the series is critical. In this way, an absolute value is taken and if the critical value of Mackinnon at different meaning levels is smaller than this absolute value, it is concluded that the series is not stationary and if it is larger than this absolute value, it is concluded that the series is a stationary series (Tar1, 2005; Y1lmaz \& Akınc1, 2011). 


\section{The PP Unit Root Test}

The PP Unit Root Test is a complementary test of the DF unit root test. PP stands for the Philips-Perron root test. The equations in the ADF test assume that the error terms are formed by a constant and independent variance. If we compare the assumptions of the PP unit root test and the ADF test; the PP root test appears to have more flexible assumptions. In the PP unit root test, as in the ADF root test, it was concluded that the null hypothesis was the unit root, in other words, the series was not stationary. On the other hand, it was concluded that the series was stationary in another hypothesis. PP stationarity test is also shown by equations 2 and 3 (Enders, 1995);

$y_{t}=\beta_{0}+\delta_{1} y_{t-1}+\varepsilon_{t}$

$y_{t}=\beta_{0}+\delta_{1} y_{t-1}+\delta_{2}\left(t-\frac{T}{2}\right)+\varepsilon_{t}$

In equations (2) and (3), T refers to the number of observations, $\varepsilon t$ refers to the distribution of error terms, $y_{t}$ refers to test series, $\alpha, \beta$ and $t$ refer to trend variables. There is an assumption that there is a weak dependence and heterogeneous distribution among the error terms in the PP test. The correction method is used with the Newey-West estimator obtained as a result of regression to eliminate autocorrelation in the PP test.

Table 2. 2010: 1Q-2019: 4Q Unit Root Test Results for Foreign Direct Investment, Consumer Price Index, Benchmark Interest Rate, Gross Domestic Product and Trade Openness Ratio

\begin{tabular}{|c|c|c|c|c|c|c|c|c|}
\hline & & & \multicolumn{3}{|c|}{$\begin{array}{c}\text { Augmented Dickey-Fuller (ADF) } \\
\text { Test }\end{array}$} & \multicolumn{3}{|c|}{ Philips-Perron (PP) Test } \\
\hline & & & with trend & $\begin{array}{l}\text { without } \\
\text { trend }\end{array}$ & $\begin{array}{c}\text { without } \\
\text { constant } \\
\text { without } \\
\text { trend }\end{array}$ & $\begin{array}{l}\text { with } \\
\text { trend }\end{array}$ & $\begin{array}{l}\text { without } \\
\text { trend }\end{array}$ & $\begin{array}{c}\text { without } \\
\text { constant } \\
\text { without } \\
\text { trend }\end{array}$ \\
\hline \multirow{4}{*}{$\begin{array}{c}\text { FDI } \\
\text { (Foreign } \\
\text { Direct } \\
\text { Investment) } \\
\text { dependent } \\
\text { variable, }\end{array}$} & \multirow{2}{*}{ Level } & $\begin{array}{c}\text { Test } \\
\text { Statistics } \\
\end{array}$ & $-4,416$ & $-5,260$ & -0.990296 & $-4,420$ & $-5,928$ & $-1,416$ \\
\hline & & Probability & 0.0011 & 0.0007 & 0.2830 & 0.0011 & 0.0001 & 0.1437 \\
\hline & \multirow{2}{*}{$\begin{array}{c}1 . \\
\text { Difference }\end{array}$} & $\begin{array}{c}\text { Test } \\
\text { Statistics } \\
\end{array}$ & $-10,040$ & $-10,130$ & $-10,187$ & $-12,001$ & $-12,896$ & $-12,189$ \\
\hline & & Probability & 0.001 & 0.001 & 0.001 & 0.0000 & 0.0000 & 0.0000 \\
\hline \multirow{4}{*}{$\begin{array}{l}\text { CPI } \\
\text { (Consumer } \\
\text { Price Index, } \\
\text { i.e. inflation } \\
\text { rate), }\end{array}$} & \multirow{2}{*}{ Level } & $\begin{array}{c}\text { Test } \\
\text { Statistics }\end{array}$ & $-2,014$ & $-2,772$ & 1,179 & $-2,111$ & $-2,912$ & $-0,640$ \\
\hline & & Probability & 0.280 & 0.215 & 0.935 & 0.241 & 0.169 & 0.433 \\
\hline & \multirow{2}{*}{$\begin{array}{c}1 . \\
\text { Difference }\end{array}$} & $\begin{array}{c}\text { Test } \\
\text { Statistics } \\
\end{array}$ & $-6,245$ & $-6,210$ & $-6,027$ & $-5,748$ & $-5,659$ & $-5,830$ \\
\hline & & Probability & 0.001 & 0.001 & 0.001 & 0.001 & 0.001 & 0.001 \\
\hline \multirow{2}{*}{$\begin{array}{c}\text { BIR } \\
\text { (Benchmark }\end{array}$} & \multirow[t]{2}{*}{ Level } & $\begin{array}{c}\text { Test } \\
\text { Statistics }\end{array}$ & $-1,890$ & $-2,702$ & $-0,493$ & $-1,955$ & $-2,782$ & $-0,425$ \\
\hline & & Probability & 0.331 & 0.214 & 0.050 & 0.304 & 0.212 & 0.523 \\
\hline
\end{tabular}


ALANYA AKADEMİK BAKIŞ DERGİSİ 4/3 (2020)

\begin{tabular}{|c|c|c|c|c|c|c|c|c|}
\hline \multirow[t]{2}{*}{$\begin{array}{l}\text { interest } \\
\text { rate), }\end{array}$} & \multirow{2}{*}{$\begin{array}{c}1 . \\
\text { Difference }\end{array}$} & $\begin{array}{c}\text { Test } \\
\text { Statistics }\end{array}$ & $-7,414$ & $-7,312$ & $-7,504$ & $-7,360$ & $-7,262$ & $-7,443$ \\
\hline & & Probability & 0.001 & 0.001 & 0.001 & 0.001 & 0.001 & 0.001 \\
\hline \multirow{4}{*}{$\begin{array}{c}\text { GDP } \\
\text { (Gross } \\
\text { Domestic } \\
\text { Product } \\
\text { Growth) }\end{array}$} & \multirow{2}{*}{ Level } & $\begin{array}{c}\text { Test } \\
\text { Statistics }\end{array}$ & $-2,846$ & $-3,010$ & $-2,340$ & $-2,890$ & $-3,104$ & $-2,335$ \\
\hline & & Probability & 0.061 & 0,142 & 0.020 & 0.055 & 0.119 & 0.021 \\
\hline & \multirow{2}{*}{$\begin{array}{c}1 . \\
\text { Difference }\end{array}$} & $\begin{array}{c}\text { Test } \\
\text { Statistics } \\
\end{array}$ & $-6,760$ & $-6,681$ & $-6,779$ & $-6,773$ & $-6,691$ & $-6,779$ \\
\hline & & Probability & 0.001 & 0.001 & 0.001 & 0.001 & 0.001 & 0.001 \\
\hline \multirow{4}{*}{$\begin{array}{c}\text { OPENNESS } \\
\text { RATIO } \\
\text { OR } \\
\text { (Openness } \\
\text { Ratio) }\end{array}$} & \multirow{2}{*}{ Level } & $\begin{array}{c}\text { Test } \\
\text { Statistics }\end{array}$ & $-5,660$ & $-4,413$ & 0,678 & $-5,386$ & $-4,209$ & 0,465 \\
\hline & & Probability & 0.001 & 0.006 & 0.858 & 0.001 & 0.010 & 0.817 \\
\hline & \multirow{2}{*}{$\begin{array}{c}1 . \\
\text { Difference }\end{array}$} & $\begin{array}{c}\text { Test } \\
\text { Statistics } \\
\end{array}$ & $-5,984$ & $-6,476$ & $-5,895$ & $-11,239$ & $-16,141$ & $-9,767$ \\
\hline & & Probability & 0.001 & 0.001 & 0.001 & 0.001 & 0.001 & 0.001 \\
\hline
\end{tabular}

According to the results of ADF and PP unit root tests analysis results are as follows. When foreign direct investment, consumer price index, benchmark interest rate, gross domestic product and openness ratio are analyzed at the level, it is observed that they are not stationary in some form. However, when the first differences are taken, it is observed that the series become stationary at a \% 1 significance level with only constant, with no constant-no trend and with both constant and trend forms.

\section{Cointegration Tests}

The existence of long-term relationships among the variables is determined by multiple and several cointegration tests in the literature. Some of these tests are Eagle-Granger two- stage integration test, Johansen maximum likelihood vector autoregressive method, Engle-Yoo three-stage cointegration test, Johansen-Juselius cointegration test, Saikkonen cointegration tests. In this study, the existence of the balanced relationship and the long-term relationship between foreign direct investment, unemployment, consumer price index, benchmark interest rate, gross domestic product and trade openness ratio were investigated by Eagle-Granger and Johansen cointegration tests.

\section{Johansen Cointegration Test Results}

After the analysis of time series, it was determined that the series in this analysis were equally stationary and the integration test was applied to this analysis. Firstly, VAR estimations were made without limitation on the level values of these variables and the appropriate number of lags was determined. The integration test allows for dynamic and comprehensive analysis of the relationships between variables in the model (Özer and Coşkun, 2011). The VAR method was first implemented by Sims. The VAR model is an improved version of the Granger causality test. Dynamic relationships between internal variables without a restriction are tried to be predicted by the VAR model (Sims, 1980). VAR analysis is based on a simultaneous 
equation model. In VAR analysis, both the internal variable and lagged values of other variables are explained. The equations used in a standard two-variable VAR analysis are:

$y_{t}=a_{10}+\sum_{i=1}^{p} a_{11 i} Y_{t-1}+\sum_{i=1}^{p} a_{12 i} X_{t-1}+u_{1 t}$

$y_{t}=a_{20}+\sum_{i=1}^{p} a_{21 i} Y_{t-1}+\sum_{i=1}^{p} a_{22 i} X_{t-1}+u_{2 t}$

Among the terms used in equation 4 and $5, a_{i 0}$ refers to the constant term, $a_{i j k}$ refers to the parameter of the $\mathrm{k}$ lag of $\mathrm{j}$ 'th variable in the i'th equation, uit refers to the error term and $p$ refers to the number of lags (Tar1, 2005). In the VAR analysis method, the lag length of the variables must be the same for maintaining symmetry in the model and for the OLS estimator to be effective. Akaike (ACI), Schwarts (SIC), Hannan-Quinn (HQ), (LR) and Final Prediction Error (FPE), and information craters are used to determine the appropriate lag length in VAR models (Johansen, 1995; Enders, 1995). Engle-Granger cointegration test was used to determine the existence of a long-term relationship between cointegrated series and multiple cointegration tests developed by Johansen and Juselius were used to determine the number of cointegrated vectors. For this, trace and maximum eigenvalue test statistics are used. The critical values used in both tests were established by Johansen and Juselius. The optimal lag length was determined before switching to the model to be estimated for this purpose.

Table 3. Selection of appropriate lag lengths for VAR model

\begin{tabular}{|c|c|c|c|c|c|c|}
\hline Lag & LogL & LR & FPE & AIC & SC & HQ \\
\hline 0 & -878.8452 & NA & $1.45 \mathrm{e}+15$ & 49.10251 & 49.32244 & 49.17927 \\
\hline 1 & -829.7469 & 81.83054 & $3.87 \mathrm{e}+14^{*}$ & 47.76372 & $49.08331 *$ & $48.22429^{*}$ \\
\hline 2 & -812.8029 & 23.53330 & $6.60 \mathrm{e}+14$ & 48.21127 & 50.63054 & 49.05566 \\
\hline 3 & -778.8006 & $37.78034^{*}$ & $5.05 \mathrm{e}+14$ & 47.71114 & 51.23008 & 48.93935 \\
\hline 4 & -741.1857 & 31.34579 & $4.16 \mathrm{e}+14$ & $47.01031 *$ & 51.62891 & 48.62233 \\
\hline
\end{tabular}

LR: Sequential Modified Likelihood Ratio (LR) Test Statistics,

FPE: Final Prediction error, AIC: Akaike Information Criteria,

SC: Schwarz Information Criteria,

HQ: Hannan- Quinn Information Criteria

In determining the lag length of the model, the appropriate number of lags is 1 according to the FPE, AIC, SC and HQ information criteria. The AIC criterion is based on the minimization of the mean error square and is rather a value taken into account in forwardlooking forecasts. On the other hand, the HQ criterion is a value that is taken into account in determining the consistent level of lag. Therefore, it is seen in the table above that the lag length 1 is stable according to the analysis result. 
Table 4. Johansen Cointegration Test Results

\begin{tabular}{|l|l|l|l|l|}
\cline { 2 - 5 } \multicolumn{2}{l|}{} & \multicolumn{2}{l}{} & \multicolumn{2}{c|}{ Maximum Eigenvalue Statistics } \\
\hline $\mathrm{H}_{0}$ & \multicolumn{2}{l}{ Trace Statistics } & \multicolumn{2}{c|}{} \\
\hline Hypothesis & Critical Value (5\%) & Test Statistics & $\begin{array}{l}\text { Critical Value } \\
(5 \%)\end{array}$ & Test Statistics \\
\hline 0 & 74,313 & 0.0209 & 31,056 & 0.1047 \\
\hline 1 & 43,257 & 0.1264 & 18,442 & 0.4588 \\
\hline 2 & 24,815 & 0.1681 & 13,649 & 0.3945 \\
\hline 3 & 11,165 & 0.2015 & 8,750 & 0.3075 \\
\hline 4 & 2,415 & 0.1201 & 2,415 & 0.1201 \\
\hline
\end{tabular}

After determining the appropriate lag numbers for the Johansen cointegration test, it is tested with the Johansen cointegration test to determine whether there is a long term relationship between the variables. Using the predicted VAR equation, Johansen cointegration was investigated and the test results are given in the table above. When the cointegration test statistics are examined, it is seen that there are 5 cointegration vectors in which the $\mathrm{H} 0$ hypothesis is rejected. It is seen that these five variables move together in the long term according to Trace and Eigenvalue tests.

\section{Error Correction Model (VECM) and Granger Causality Test}

The error correction model VECM is estimated to investigate the short-term dynamics of two or more series moving together in the long run. The cointegration equations obtained as a result of the estimation were tested with a Granger causality test and the direction of causality relationships between the variables was determined.

The VECM model is represented by the following equation;

$\Delta y_{t}=\prod y_{t-1}+\sum_{i=1}^{p-1} \Gamma_{11 i} \Delta y_{t-1}+B_{x t}+\varepsilon_{t}$

$\prod=\sum_{i=1}^{p-1} \mathrm{~A}_{i}-1, \quad \sum_{j=i+1}^{p-1} \mathrm{~A}_{j}$

If there is a cointegration relationship between the variables in the vector rank, $\operatorname{rank}\left(\prod\right)=\mathrm{r}<$ $k$.

There are two $k x r$ matrices such as $\alpha$ and $\beta$ that provide $\prod=\alpha \beta$ equation. $\alpha$ matrix is composed of coefficients of adjustment speed, $\beta$ matrix consists of cointegration vectors (Johansen, 1991). VECM was estimated because a cointegration relationship was detected between the variables. Equations showing the cointegration relationships obtained from this estimate will be tested in the Granger causality test later. Granger causality test was used to investigate the causality between the variables in the study. The significance of the lagged values of the independent variable in the equations is tested in the Granger causality test (Granger and Clive, 1969). 
Table 5. Granger Causality Test 1

\begin{tabular}{|c|c|c|c|}
\hline \multicolumn{5}{|c|}{ Dependent Variable: D FDI } \\
\hline & Chi square value & Ser. Degree & Probability \\
\hline DCPI & 0.073815 & 1 & 0.7859 \\
\hline DBR & 0.045424 & 1 & 0.8312 \\
\hline DGDP & 2.022230 & 1 & 0.0015 \\
\hline DOPENNESS RATIO & 2.346246 & 1 & 0.0162 \\
\hline ALL & 6.286230 & 4 & 0.6833 \\
\hline
\end{tabular}

As can be seen in the table, according to the causality test results, when there is a change in foreign direct investment between the first quarter of 2010 and the fourth quarter of 2019, the gross domestic product and openness ratio are affected in the short term. In other words, foreign direct investment is the Granger causal of the gross domestic product and openness ratio.

Table 6. Granger Causality Test 2

\begin{tabular}{|c|c|c|c|}
\hline \multicolumn{4}{|c|}{ Dependent variable: DBIR } \\
\hline & Chi square value & Ser. Degree & Probability \\
\hline DCPI & 0.106930 & 1 & 0.7437 \\
\hline D FDI & 0.004676 & 1 & 0.9455 \\
\hline DGDP & 0.132985 & 1 & 0.7154 \\
\hline DOPENNESS RATIO & 0.003479 & 1 & 0.9530 \\
\hline ALL & 0.425217 & 4 & 0.9804 \\
\hline
\end{tabular}

As can be seen in the table, according to the causality test results, when there is a change in the benchmark interest between the first quarter of 2010 and the fourth quarter of 2019, other independent variables are not affected.

Table 7. Granger Causality Test 3

\begin{tabular}{|c|c|c|c|}
\hline \multicolumn{4}{|c|}{ Dependent variable: DCPI } \\
\hline & Chi square value & Ser. Degree & Probability \\
\hline DBR & 9.618613 & 1 & 0.0019 \\
\hline D FDI & 0.008640 & 1 & 0.9259 \\
\hline DGDP & 0.254826 & 1 & 0.6137 \\
\hline DOPENNESS RATIO & 0.162379 & 1 & 0.6870 \\
\hline ALL & 12.18038 & 4 & 0.0161 \\
\hline
\end{tabular}

As can be seen in the table, according to the causality test results, between the first quarter of 2010 and the fourth quarter of 2019, when there is a change in the consumer price index, the benchmark interest rate is affected in the short term. In other words, the benchmark interest rate is the Granger causal of the Consumer price index. 
Table 8. Granger Causality Test 4

\begin{tabular}{|c|c|c|c|}
\hline \multicolumn{4}{|c|}{ Dependent variable: DGDP } \\
\hline & Chi square value & Ser. Degree & Probability \\
\hline DBR & 0.052403 & 1 & 0.8189 \\
\hline DCPI & 0.570254 & 1 & 0.4502 \\
\hline D FDI & 0.439319 & 1 & 0.5075 \\
\hline DOPENNESS RATIO & 2.600182 & 1 & 0.1069 \\
\hline ALL & 8.381476 & 4 & 0.0786 \\
\hline
\end{tabular}

As can be seen in the table, according to the causality test results, when there is a change in the gross domestic product in the period between the 1st quarter of 2010 and the 4th quarter of 2019, other independent variables are not affected.

Table 9. Granger Causality Test 4

\begin{tabular}{|c|c|c|c|}
\hline \multicolumn{4}{|c|}{ Dependent Variable: DOPENNESS RATIO } \\
\hline & Chi square value & Ser. Degree & Probability \\
\hline DBR & 0.119712 & 1 & 0.7293 \\
\hline DCPI & 0.006416 & 1 & 0.9362 \\
\hline D FDI & 7.875097 & 1 & 0.0050 \\
\hline DGDP & 1.904735 & 1 & 0.1675 \\
\hline ALL & 9.178827 & 4 & 0.0568 \\
\hline
\end{tabular}

As can be seen in the table, according to the causality test results, when there is a change in the trade openness ratio between the first quarter of 2010 and the fourth quarter of 2019, foreign direct investment is affected in the short term, in other words, the foreign direct investment is the Granger causality of the trade openness ratio.

Table 10. 2010: 1Q-2019: 4Q Error Correction Model for Foreign Direct Investment, Consumer Price Index, Benchmark Interest Rate, Gross Domestic Product and Trade Openness Ratio

\begin{tabular}{|c|c|c|c|c|}
\hline Variable & Coefficient & Std. Deviation & Statistical value & $\begin{array}{c}\text { Probability } \\
\text { Value }\end{array}$ \\
\hline DCPI & 768.0844 & 103.8102 & 7.398929 & 0.0000 \\
\hline DGDP & 247.3144 & 99.06050 & 2.496600 & 0.0177 \\
\hline DOPENNESS RATIO & 4.716356 & 109.0659 & 0.043243 & 0.9658 \\
\hline ERROR TERMS (-1) & -0.906928 & 0.187381 & -4.840016 & 0.0000 \\
\hline C & 122.9350 & 244.3295 & 0.503153 & 0.6182 \\
\hline
\end{tabular}

It is seen in the table above that foreign direct investment is a dependent variable; consumer price index, benchmark interest rate, gross domestic product and openness ratio are independent variables and there is a short term relationship between variables. As can be seen in the table, 1 unit change in the independent variables of a consumer price index, benchmark interest rate, gross domestic product and openness ratio has a 10-term effect on foreign direct investment in the period we are considering. In other words, a 1-unit change in independent variables stabilized foreign direct investment at the end of 10 periods. 


\section{DISCUSSION, CONCLUSION AND RECOMMENDATIONS}

International capital movements have been considered an important part of the balance of payments after the 1950 s and foreign direct investment became a significant item of the financial account. Multinational enterprises investing around the world have preferred to make such investments, especially in developed countries with large markets where economic and political stability is achieved. As of the 1970s, direct foreign enterprises have become more on the agenda of world countries with a decrease in transportation and communication costs and the development of global production processes. By the 1980s, developing countries participated in the globalization process that started in developed countries and liberalization tendency gained momentum in most countries. This has abolished the economic boundaries between countries, accelerated the free movement of foreign capital and increased total foreign capital transaction volume.

In this study, by using quarterly data between the first quarter of 2010 and the fourth quarter of 2019, the relationships between foreign direct investments and consumer price index, that is, inflation rate, benchmark interest rate, gross domestic product and trade openness ratio were examined. Foreign direct investment is considered as dependent variable and consumer price index, benchmark interest rate, gross domestic product growth rate and trade openness ratio are considered as independent variables. Johansen cointegration tests were applied to explain the long-term relationship between variables. As a result of the tests, it was concluded that the variables were cointegrated in the long term, in other words, the variables were related to each other and moved in the same direction in the long term. Granger causality test was used to investigate the causality between the variables in the study. Thereby revealed that obtained results are compatible with studies in the literature such as Aseidu (2002), Dumludağ and Şükrüoğlu (2007), Michailova and Ang (2008), Pradhan (2009), Gürsoy and Kalyoncu (2012), Sunde (2017).

VECM model has been applied instead of the VAR model because the variables move together in the long term. As a result of VECM analysis; it was found that 1 unit change in all of the consumer price index, benchmark interest rate, gross domestic product and trade openness ratio has a 10-term effect on foreign direct investment. In other words, when there is a 1 unit change in the independent variables, it is seen that the dependent variable comes to equilibrium after 10 periods.

The factors which negatively affect capital inflow in Turkey are volatile economic growth rates, high inflation, high interest rates and economic-politic instabilities. Additionally, Turkey is a country which cannot fix balance of payments and cannot achieve tax reforms and privatization requirements. Other adverse factors are high bureaucracy and the fact that inaccurate tax law and trade law fail to complete accurate foreign capital law. If these issues are corrected, investment environment will be developed and Turkey can achieve the top ranks among developing countries regarding foreign direct investment inflows. It can be suggested for investors to monitor these variables closely and make decisions according to long term relationships between variables. 


\section{REFERENCES}

ALGUACIL, M. T., CUADROS, A. \& ORTS, V. (2002). "Foreign direct investment, exports and domestic performance in Mexico: A causality analysis". Economic Letters, 77: 371-376.

ALICI, A. A. \& UCAL, M. Ş. (2003). "Foreign direct investment, exports and output growth of Turkey: causality analysis". European Trade Study Group (ETSG) Fifth Annual Conference (1-17.pp.). http: //www.etsg.org/ETSG2003/papers/alici.pdf

ASEIDU, E. (2002). "On the Determinants on Foreign Direct Investment to Developing countries: Is Africa Different?”. World Development, 30(1): 107-119.

ASTERIOU, D. \& HALL, S. G. (2007). Applied econometrics. Palgra and Macmillan, New York.

CAMPOS, N. F. \& KINOSHITA, Y. (2003). "Why Does FDI Go Where it Goes? New Evidence from the Transition Economies". IMF Working Papers 03/228, International Monetary Fund.

DUMLUDAĞ, D. \& ŞÜKRÜOĞLU, D. (2007). "The impact of macroeconomic and institutional variables on foreign direct investment flows in emerging market". Marmara Üniversitesi İİBF Dergisi, 23(2): 133-166.

EMIRMAHMUTOĞLU, F. \& KÖSE, N. (2011). "Testing for Granger causality in heterogeneous mixed panels". Economic Modelling, 28: 870-876.

ENDERS, W. (1995). Applied econometric time series. John Wiley \& Sons Inc, New York.

GRANGER, C.WJ. (1969). "Investigating causal relations by econometric models and crossspectral methods". Econometrica, 37(3): 424-438.

GRANGER, C.WJ. \& NEWBOLD, P. (1974). "Spurious in econometrics". Journal Of Economics, 2: 111-120.

GÜRSOY, F. \& KALYONCU, H. (2012)." Foreign Direct Investment and Growth Relationship in Georgia". International Journal of Economics and Financial Issues, 2(3): 267-271.

HANSEN, H., RAND. J. \& TARP. F. (2003). “Are FDI Inflows Complements or Substitutes Across Borders: Empirical Evidence from Five Asian Economies". MPRA Paper 72834, University Library of Munich, Germany.

JOHANSEN, S. (1991). "Estimation and hypothesis testing of cointegration vectors in gaussian vector autoregressive models". Econometrica, 59:1551-1580.

JOHANSEN, S. (1995). Likelihood-based inference in cointegrated vector autoregressive models. Oxford University Press, England

KOYUNCU, F.T. (2010). “Türkiye'de Seçilmiş Makroekonomik Değişkenlerin Doğrudan Yabancı Sermaye Yatırımları Üzerindeki Etkisinin Yapısal VAR Analizi:1990-2009 Dönemi”. Ekonomi Bilimleri Dergisi, 2(1): 55-62. 
MARJANOVIĆ, V. \& MARJANOVIĆ, M. (2014). "Simulation of industrial development as the key determinant of the strategy of Serbia economic restructuring". Teme, 38(4): 1425-1444.

MİCHAİLOVA, S. \& ANG, S. H. (2008). "Institutional Explanations of Cross-Alliance Modes: The Case of Emerging Economies Firms". Management International Review: 551-576.

MONTERO, A. P. (2008). "Macroeconomic deeds, not reform words: The determinants of foreign direct investment in Latin America". Latin American Research Review, 43 (1): 55-83.

ÖZER, M. \& COŞKUN, İ. O. (2011). "Sustainability of Turkish current account deficit in the post crisis period”. Nibes Transactions, 5(2): 67-82.

PORTILlA, P.G., MAZA, A., VILlaVERDE, J. \& HIERRO, M. (2016). "Foreign direct investment in the Spanish regions: What are the influencing factors? ". Investigaciones Regionales - Journal of Regional Research, 35: 67-82.

PRADHAN, R. P. (2009). "The FDI-led- growth hypothesis in ASEAN-5 countries: Evidence from cointegrated panel analysis". International Journal of Business and Management, 4(12): 153-164.

RANĐELOVIĆ, P. M, MILIĆ, J. V. \& KOSTADINOVIĆ, I. (2017). "Market size as a determinant of the foreign direct investment in flows in the Western Balkans countries". Facta Universitatis, Series: Economics and Organization, 14(2): 93 -104.

REICHERT, U.N. \& WEINHOLD. D. (2001). "Causality Tests for Cross-Country Panels: New Look at FDI and Economic Growth in Developing Countries". Oxford Bulletin of Economics and Statistics, 63(2): 153-171.

SIMS, C. (1980). "Macroeconomics and reality”. Econometrica, 48: 1-49.

SUNDE, T. (2017). "Foreign Direct Investment, Exports and Economic Growth: ADRL and Causality Analysis for South Africa". Research in International Business and Finance, 41: 434-444.

ŞAHBAZ, A. (2014). "Sabit Sermaye Yatırımları ve Ekonomik Büyüme İlişkisi: Panel Nedensellik Analizi”. Niğde Üniversitesi İİBF Dergisi, 7(1): 1-12.

TARI, R. (2005). Ekonometri. Kocaeli Üniversitesi Yayınları, İstanbul.

TOPALLI, N. (2016). "Doğrudan Sermaye Yatırımları, Ticari Dışa Açıklık ve Ekonomik Büyüme Arasındaki İlişki: Türkiye ve BRICS Ülkeleri Örneği”. Doğuş Üniversitesi Dergisi, 17 (1): 83-95.

VILLAVERDE, J. \& MAZA, A. (2012). "Foreign direct investment in Spain: Regional distribution and determinants". International Business Review, 21(4): 722-733.

YILMAZ, Ö. \& AKINCI, M. (2011). "İktisadi büyüme ile cari işlemler bilançosu arasındaki ilişki:Türkiye örneği””. Atatürk Üniversitesi Sosyal Bilimler Enstitüsü Dergisi, 15 (2): 363-377. 
YORULMAZ, Ö., YAKUT, S.G. \& GACAR, B.K. (2018). "Doğrudan Yabancı Yatırımları Etkileyen Faktörlerin Çok Değişkenli İstatistiksel Yöntemler İle İncelenmesi”. Uluslararası İnsan Çalışmaları Dergisi, 1(2): 157-171. 